Article

\title{
Functional and Bioactive Properties of Protein Extracts Generated from Spirulina platensis and Isochrysis galbana T-Iso
}

\author{
Stephen Bleakley ${ }^{1,2}$ and Maria Hayes ${ }^{1, *}$ \\ 1 Food Biosciences, Teagasc Food Research Centre, Ashtown, D15 DY05 Dublin, Ireland; \\ Stephen.Bleakley12@gmail.com \\ 2 School of Biological Sciences, College of Sciences and Health and Environment, Sustainability and Health \\ Institute, DIT Kevin Street, D08 NF82 Dublin, Ireland \\ * Correspondence: Maria.Hayes@teagasc.ie; Tel.: +353-1-8059957
}

check for updates

Citation: Bleakley, S.; Hayes, M. Functional and Bioactive Properties of Protein Extracts Generated from Spirulina platensis and Isochrysis galbana T-Iso. Appl. Sci. 2021, 11, 3964. https://doi.org/10.3390/ app11093964

Academic Editor: Anna Iwaniak

Received: 18 February 2021

Accepted: 21 April 2021

Published: 27 April 2021

Publisher's Note: MDPI stays neutral with regard to jurisdictional claims in published maps and institutional affiliations.

Copyright: (c) 2021 by the authors Licensee MDPI, Basel, Switzerland. This article is an open access article distributed under the terms and conditions of the Creative Commons Attribution (CC BY) license (https:// creativecommons.org/licenses/by/ $4.0 /)$.
Featured Application: The heart health-beneficial activities of algal proteins extracted using a protein extraction method involving aqueous sonication, precipitation and dialysis were identified. In addition, proteins were found to have techno-functional attributes that could potentially be used in the development of meat substitute products or alkaline beverages, based on the oilholding capacities and solubility of the proteins.

\begin{abstract}
There is growing consumer demand for food products derived from microalgae, driven largely by the perceived health benefits associated with them. The functional and bioactive potential of proteins isolated from two microalgae-Spirulina sp. and Isochrysis galbana T-Iso-were determined. The results obtained show the potential of microalgal protein extracts for use in the beverage industry, based on solubility values and other functional characteristics, including water and oil holding capacities, foaming, emulsifying activities and stabilities, water activities, solubility and $\mathrm{pH}$. The solubility of algal proteins was $\mathrm{pH}$-dependent, and they were largely insoluble at $\mathrm{pH}$ values between 2 and 11 . However, the proteins were increasingly soluble at a $\mathrm{pH}$ of 12 , and they have potential use in formulating foods with higher viscosities or gels, where they could act as fillers to strengthen networks. Compared with whey and flaxseed proteins, the Spirulina sp. protein extract had a superior oil-holding capacity $(\mathrm{OHC})$. The $\mathrm{OHC}$ is important in developing texture in food products such as meats. Overall, better foam stability was observed for both Spirulina sp. and Isochrysis sp. soluble protein extracts, compared with flaxseed protein at $\mathrm{pH}$ values from 2 to 10 over a period of $120 \mathrm{~min}$. The foam capacity and stability increase the physical properties of foods. However, the emulsion activity and stability values for soluble algal protein extracts were less than the values observed for flaxseed and whey proteins. Algal proteins would not be suitable for use in creaming and food processing involving flocculation. In addition, algal protein extracts inhibited Angiotensinconverting enzyme-I (ACE-I) and renin, and they have potential for use in functional food ingredient applications to maintain heart health and also to act as meat substitutes.
\end{abstract}

Keywords: Spirulina sp.; Isochrysis galbana T-Iso; angiotensin-I-converting enzyme (ACE-I) inhibition; renin inhibition; protein; solubility; emulsifying; foaming; water activity

\section{Introduction}

There are over 30,000 microalgae species; however, fewer than ten species are commercially produced [1,2], and only two species are recognized for sale within the European Union with European Food Safety Authority (EFSA) approval. Select microalgae contain protein levels based on a dry matter basis, similar to some plant and animal sources of protein. The reported protein content of Spirulina platensis varies from $65 \%$ to $77 \%$ of the dry matter, a value greater than the protein content of soy flour (37\%), chicken (24\%), fish (24\%), beef $(22 \%)$ and skimmed milk (36\%) [3]. Isochrysis sp. reportedly contains $30.5 \%$ protein 
on a dry weight basis [4]. Although microalgae were used throughout history as a source of food [5], the industrial production of microalgal protein is still a developing field of research due to technical difficulties regarding cultivation, cost of cultivation and processing and limited knowledge regarding their functional, nutritional and bioactive attributes.

Several research groups have looked at extracting proteins from microalgae, including Spirulina sp. previously. Ultrasound followed by sugaring out with ionic flotation [6] and ultrasound alone were applied to Spirulina sp. previously to disrupt the cell wall [7]. Previously, Safi et al. determined the proportion of proteins released from the microalgae Porphyridium cruentus, Arthrospira platensis, Chlorella vulgaris, Nannochloropsis oculata and Haematococcus pluvialis, following both mechanical and chemical treatments with a highpressure disruptor and $2 \mathrm{~N} \mathrm{NaOH}$ [8]. The proportion of essential and non-essential amino acids in the extracts was higher in the alkaline and high-pressure treated samples compared with the untreated algal biomass [8]. A study by Garcia-Vaquero et al. assessed the functional properties of protein extracts generated from the brown alga Himanthalia elongata (Linnaeus) S. F. Gray [9]. This study suggested that protein extracted from this alga could be suitable for use in the formulation of a wide variety of food products, including sausages, breads, cakes, soups and salads [9]. What protein extraction method is considered the best method depends on the alga treated and the structure of the algal cell wall. Cost is also a factor that should be considered. The type of alga treated, seasonal variations in the quantities of proteins in the starting materials and method all play a part in determining the yield of protein obtainable from a microalga. In addition, the health properties of Spirulina sp. proteins were looked at previously [10]. Protein extracts from microalgae, including Dunaliella sp., at an industrial scale can produce more protein compared with terrestrial plant harvests (about 100 times greater yield).

The aim of this work was to generate protein extracts from the algae Spirulina platensis and Isochrysis galbana T-Iso using an aqueous sonication method, followed by precipitation with ammonium sulphate and dialysis procedure, as described previously by Galland-Irmouli et al. [11]. The functional and bioactive attributes of the extracted proteins were determined and compared to protein sources including whey protein isolate and flaxseed protein, which are used widely in the food industry as techno-functional ingredients.

\section{Materials and Methods}

\subsection{Materials and Algae Used in This Study}

Microalgae were kindly cultivated and supplied by the University of Almeria in Andalucía, Spain. Isochrysis galbana T-Iso was grown in tubular reactors using saltwater and fertilizers as a cultivation medium. Spirulina platensis was cultivated in an open raceway reactor using fertilizers as a growth medium and with $\mathrm{pH}$ control by means of the addition of sodium bicarbonate. The samples were received in freeze-dried form and subsequently stored at $-80{ }^{\circ} \mathrm{C}$ until further use. BioZate ${ }^{\circledR}$, a whey protein isolate (BioZate, Davisco Foods, Le Sueur, MN, USA), and defatted golden flaxseed meal (Glanbia Nutritionals, Chicago, IL, USA) were used as dairy and cereal protein comparisons in the assessment of the functional properties of the microalgal proteins. Sigma Aldrich (Sigma Aldrich, Dublin, Ireland) supplied the ammonium sulphate. Angiotensin-1-converting enzyme (ACE-I; EC 3.4.15.1) inhibition was determined using the ACE-I inhibition colorimetric assay kit supplied by Dojindo Laboratories (Dojindo Laboratories, Kumamoto, Japan). Captopril@ was supplied by Sigma Aldrich (Steinheim, Germany). Renin inhibition was determined using a renin activity fluorometric assay kit from BioVision Inc. (Cambridge bioscience, Cambridge, UK). The specific renin inhibitor Z-Arg-Arg-Pro-Phe-His-Sta-Ile-His-Lys-(Boc)OMe, which was used as a positive control as detailed in previous studies [12,13], was supplied by Sigma Aldrich (Steinheim, Germany).

\subsection{Protein Extraction and Determination}

Crude protein extracts were generated from microalgae using the method previously described by Galland-Irmouli et al., which will be referred to as the traditional protein 
extraction method [11]. Briefly, microalgae were added independently to Milli-Q ultrapure water at a concentration of $2 \%(w / v)$ and sonicated using a Bran sonic ${ }^{\circledR} 3510 \mathrm{EMT}$ (Branson Ultrasonic SA, Urdorf, Switzerland)) at $42 \mathrm{kHz}$ for $1 \mathrm{~h}$. The treated biomass was stirred overnight at $4{ }^{\circ} \mathrm{C}$ and centrifuged (Sorvall LYNX 6000 super speed centrifuge, Thermo Scientific, UK) at $10,000 \times g$ for $1 \mathrm{~h}$ at $4{ }^{\circ} \mathrm{C}$. The supernatant was subsequently collected and stored at $4{ }^{\circ} \mathrm{C}$, while the pellet was resuspended in ultrapure water at a concentration of $4 \%(w / v)$. The resuspended biomass was sonicated for $1 \mathrm{~h}$, stirred overnight at $4{ }^{\circ} \mathrm{C}$ and centrifuged at $10,000 \times g$ for $1 \mathrm{~h}$ at $4{ }^{\circ} \mathrm{C}$. The supernatants were pooled and saturated with $80 \%$ ammonium sulphate (Sigma Aldrich, Dublin, Ireland). This was followed by stirring for $1 \mathrm{~h}$ at $4{ }^{\circ} \mathrm{C}$ and centrifugation at $17,000 \times \mathrm{g}$ for $1 \mathrm{~h}$ at $4{ }^{\circ} \mathrm{C}$. The pellet was resuspended and dialyzed overnight at $4{ }^{\circ} \mathrm{C}$ using Thermo scientific snakeskin ${ }^{\mathrm{TM}} 3.5 \mathrm{kDa}$ molecular weight cut-off (MWCO) tubing (Fischer Scientific, Waltham, NH, USA). The dialyzed protein extracts were freeze-dried using an industrial-scale freeze drier, namely the FD 80 model (Cuddon Engineering, Marlborough, New Zealand), and subsequently stored at $-20{ }^{\circ} \mathrm{C}$ until further use.

The generated protein extracts underwent initial proximate quality analysis to determine the protein, ash and lipid content. The yield of extracted protein relative to the dry biomass of the freeze-dried extracts was determined using a LECO FP628 protein analyzer (LECO Corp., St. Joseph, MI, USA) based on the Dumas method and according to AOAC method 992.15, as referenced previously [14]. A conversion factor of 4.4 was used to compute the protein content of the extracts in the microalgal protein extracts [15]. The yield of extracted protein relative to the dry biomass was calculated as g protein in the crude protein extract/g alga dry weight (DW) biomass.

\subsection{Total Amino Acid (TAA) and Free Amino Acids (FAAs) Composition}

The total amino acid composition (free and bound amino acids) and free amino acids (free) of the protein extracts generated from Spirulina sp. and Isochrysis sp. were determined. To determine the TAA, the protein extracts were hydrolyzed using $6 \mathrm{M} \mathrm{HCL}$ at $110^{\circ} \mathrm{C}$ for $23 \mathrm{~h}$, as described previously by Hill et al. [16]. The samples were then de-proteinized by mixing equal volumes of $24 \%(w / v)$ tri-chloroacetic acid and the sample. These were allowed to stand for $10 \mathrm{~min}$ at room temperature before centrifugation at $14,400 \times g$ for $10 \mathrm{~min}$. The supernatants were removed and diluted with a $0.2 \mathrm{M}$ sodium citrate buffer at a $\mathrm{pH}$ of 2.2 to give approximately $250 \mathrm{nmol}$ of each amino acid residue, based on the known molecular masses of amino acids. The samples were then diluted 1 in 2 with the internal standard norleucine to give a final concentration of $125 \mathrm{nmol} / \mathrm{mL}$. Amino acids were quantified using a Jeol JLC-500/V amino acid analyzer (Jeol (UK) Ltd., Garden city, Herts, UK) fitted with a Jeol $\mathrm{Na}^{+}$high-performance cation exchange column. The free amino acid analysis was carried out without sample hydrolysis and by diluting the samples 1 in 2 with an internal standard (norleucine) to give a final concentration of $125 \mathrm{nmol} / \mathrm{L}$. FAAs were quantified using the Jeol JLC- 500/V amino acid analyzer (Jeol (UK) Ltd., Garden city, Herts, UK).

\subsection{Protein Size Composition and Polyacrylamide Gel Electrophoresis}

The protein size composition was measured by preparing $1 \%$ algal protein extracts $(w / v)$ with ultrapure water adjusted to a $\mathrm{pH}$ of 12 using $1 \mathrm{M} \mathrm{NaOH}$ to increase the solubility of the protein. The samples were shaken for $45 \mathrm{~min}$ and centrifuged at $4000 \times \mathrm{g}$ for $30 \mathrm{~min}$. The insoluble protein pellet was stored at $-20^{\circ} \mathrm{C}$. The Amicon ultra-15 centrifugal filter units (Merck Millipore, Cork, Ireland) were washed with ultrapure water. Algal protein suspensions were first added to these units with a 3-kDa molecular weight cut-off (MWCO) filter and centrifuged at $5000 \times g$ for $1 \mathrm{~h}$, as per the manufacturer's instructions. The permeate was stored at $-20^{\circ} \mathrm{C}$, while the retentate was made up to $12 \mathrm{~mL}$ and added to the filter units with a $10 \mathrm{kDa}$ MWCO and centrifuged at $5000 \times \mathrm{g}$ for $30 \mathrm{~min}$. This process was repeated using 30,50 and $100 \mathrm{kDa}$ MWCO filters. The permeates were stored at $-20{ }^{\circ} \mathrm{C}$. The samples were freeze-dried using an industrial-scale freeze drier, namely 
the FD 80 model (Cuddon Engineering, Marlborough, New Zealand), then weighed, and the percentage values were calculated. Tris-tricine SDS-PAGE was performed using a Mini-PROTEAN ${ }^{\circledR}$ electrophoresis unit (Bio-Rad laboratories, Hercules, CA, USA) using Mini-PROTEAN ${ }^{\circledR} 10-20 \%$ Tris-tricine precast gels (Bio-Rad laboratories, Hercules, CA, USA). Protein separation was performed according to the manufacturer's instructions. Briefly, the protein extracts dissolved in $\mathrm{ddH}_{2} \mathrm{O}(20 \mathrm{mg} / \mathrm{mL})$ were diluted $1: 1$ with a loading buffer containing $200 \mathrm{mM}$ Tris-HCL pH 6.8, 2\% SDS, 40\% glycerol, $0.04 \%$ Coomassie Blue G- 250 and $350 \mathrm{mM}$ DTT. The samples were heated at $95^{\circ} \mathrm{C}$ for $10 \mathrm{~min}$ and loaded $(10 \mu \mathrm{L}$ of each sample in each well) in the pre-cast gels in the electrophoresis unit in the presence of a running buffer containing $100 \mathrm{mM}$ Tris-base, $100 \mathrm{mM}$ tricine and $0.1 \%$ SDS. The running conditions were 30-35 mA for $3 \mathrm{~h}$ and $15-20 \mathrm{~mA}$ for $2 \mathrm{~h}$. The pre-stained precision plus protein TM Dual Xtra molecular mass marker (250-2 kDa, Bio-Rad, Dublin, Ireland) was used. All images were analyzed using Quantity One ${ }^{\circledR}$ software version 4.5.2 (Bio-Rad laboratories, Hercules, CA, USA).

\subsection{Determination of the $\mathrm{pH}$ of Protein Extracts}

The freeze-dried algal protein extracts were resuspended in ultrapure water at a concentration of $1 \%(w / v)$, and the $\mathrm{pH}$ was measured using a $\mathrm{pH}$ meter (Orion, model 420 A-Thermo Orion, Cambridge shire, UK).

\subsection{Water Activity $\left(a_{w}\right)$}

The water activity $\left(\mathrm{a}_{\mathrm{W}}\right)$ value of the freeze-dried algal protein extracts was measured using an Aqua Lab water activity system (Pullman, Washington, DC, USA). The water activity was measured at $22.4 \pm 1.6^{\circ} \mathrm{C}$.

\subsection{Water-Holding Capacity (WHC) and Oil-Holding Capacity (OHC) of Protein Extracts}

The water-holding capacity (WHC) and oil-holding capacity (OHC) of the generated protein extracts were assessed according to the previously published method of Bencini [17] with slight modifications. The algal protein extracts were mixed with water or vegetable oil at a concentration of $1 \%(w / v)$ using a vortex mixer (Henry Troemner, Thorofare, NJ, USA) for $1 \mathrm{~min}$. The mixed protein extracts were allowed to stand for $30 \mathrm{~min}$ and then centrifuged at $2200 \times \mathrm{g}$ for $30 \mathrm{~min}$. The supernatants were decanted, and the tubes containing the pellet were weighed. The WHC and OHC were calculated as grams of water or oil held by $1 \mathrm{~g}$ of algae protein extract using the following formula:

$$
\mathrm{WHC} / \mathrm{OHC}=\mathrm{g} \mathrm{H}_{2} \mathrm{O} \text { or oil } / \mathrm{g} \text { protein extract }=\mathrm{W}_{2}-\mathrm{W}_{1} / \mathrm{W}_{0} \times 100
$$

where $W_{0}$ is the weight of the dry sample $(g), W_{1}$ is the weight of the tube plus the dry sample $(\mathrm{g})$ and $\mathrm{W}_{2}$ is the weight of the tube plus the pellet following removal of the supernatant $(\mathrm{g})$.

\subsection{Solubility}

The solubility of the algal protein extracts was determined based on the method by Beuchat et al. [18] with slight modifications. The algal protein extracts were prepared in ultrapure water at a concentration of $1 \%(w / v)$, and the $\mathrm{pH}$ was adjusted to between 2 and 12 using $1 \mathrm{M} \mathrm{NaOH}$ and $1 \mathrm{M} \mathrm{HCl}$. The suspended samples were mixed at room temperature for $45 \mathrm{~min}$ using a Multi-Reax vibrating shaker (Heidolph, Germany), and centrifuged at $4000 \times \mathrm{g}$ for $30 \mathrm{~min}$ at $4{ }^{\circ} \mathrm{C}$. The amount of soluble protein was determined in the supernatant using the Quanti-Pro BCA Assay Kit (Sigma, St. Louis, MO, USA) as per the manufacturer's instructions. The percentage of solubility of the protein extract at each $\mathrm{pH}$ point was calculated based on the total protein content at full dispersion using the following formula:

$$
\mathrm{S}(\%)=\left(\mathrm{C}_{\text {sup }} / \mathrm{C}_{\text {tot }}\right) \times 100 \%
$$


where $\mathrm{S}$ is the solubility, $\mathrm{C}$ is the concentration of protein, $\mathrm{C}_{\text {sup }}$ is the concentration of protein in the supernatant measured using the $\mathrm{BCA}$ assay and $\mathrm{C}_{\text {tot }}$ is the concentration of protein in the total fraction.

\subsection{Foaming Capacity and Stability}

The foaming capacity (FC) of the algal protein extracts was examined using the method outlined by Poole et al. with slight modifications [19]. The algal protein extracts were prepared at a concentration of $1.5 \%(w / v)$ in ultrapure water. The $\mathrm{pH}$ values of the samples were adjusted to 2, 4, 6, 8 and 10 using $1 \mathrm{M} \mathrm{NaOH}$ and $1 \mathrm{M} \mathrm{HCl}$. The protein suspensions were homogenized using a T25 Ultra-Turrax homogenizer $\left(\right.$ IKA $^{\circledR}$, Staufen im Breisgau, Germany) for 1 min at 10,000 RPM. The volumes of the protein suspensions before homogenization and foam generated after homogenization were measured using a graduated cylinder. $\mathrm{F}_{\mathrm{C}}$ was calculated as a percentage of the initial protein suspension volume using the following formula:

$$
\mathrm{F}_{\mathrm{C}}=\mathrm{V}_{\mathrm{F}} / \mathrm{V}_{0} \quad \times 100
$$

where $F_{c}$ is the foaming capacity, $V_{F}$ is the volume of foam after homogenization and $V_{0}$ is the initial volume of the protein suspension before homogenization. Foaming stability was expressed as a percentage of the initial foam volume and determined by measuring the volume of foam at 15,30, 60, 90 and $120 \mathrm{~min}$ after homogenization.

\subsection{Emulsifying Activity and Stability (EAI and ESI) of Protein Extracts}

The emulsion activity index (EAI) was carried out according to the turbidimetric method outlined by Pearce and Kinsella [20] with slight modifications. A 1\% protein solution was made by adding a sample amount corresponding to $120 \mathrm{mg}$ protein to $12 \mathrm{~mL}$ $\mathrm{ddH}_{2} \mathrm{O}$. Four milliliters of sunflower oil, rapeseed oil, olive oil or groundnut oil was then added separately to the protein solution and homogenized using a T25 Ultra-Turrax homogenizer (IKA ${ }^{\circledR}$, Staufen im Breisgau, Germany) for 1 min at 14,000 RPM. A $50 \mu \mathrm{L}$ aliquot was taken from the bottom of the tube and added to $5 \mathrm{~mL}$ of $0.1 \%$ SDS at 0 and $10 \mathrm{~min}$ after homogenization. The absorbance of the diluted solution was measured at $500 \mathrm{~nm}$, and the EAI and ESI were calculated as follows:

$$
\operatorname{EAI}\left(\mathrm{m}^{2} / \mathrm{g}\right)=2 \times \mathrm{T} \times \mathrm{A}_{0} / \theta \times \mathrm{c}
$$

where $\mathrm{T}$ is the turbidity (2.303), $\mathrm{A}_{0}$ is the absorbance measured at $500 \mathrm{~nm} 0 \mathrm{~min}$ after homogenization, $\theta$ is the oil volumetric fraction of the homogenized solution $(0.25)$ and $c$ is the protein concentration $(0.1 \mathrm{~g} / \mathrm{mL})$ :

$$
\mathrm{ESI}(\min )=\mathrm{A}_{0} \times \Delta_{\mathrm{t}} / \Delta \mathrm{T}
$$

where $\Delta_{\mathrm{t}}$ is the change in time $(10 \mathrm{~min})$ and $\Delta \mathrm{T}$ is the change in turbidity $\left(\mathrm{A}_{0}-\mathrm{A}_{10}\right)$.

\subsection{ACE-I and Renin Inhibitory Activity of Extracted Soluble Proteins}

An ACE-I (angiotensin-converting enzyme-I) inhibition bioassay of the microalgal proteins was carried out according to the manufacturer's instructions (ACE Kit-WST, Dojindo Laboratories, Kumamoto, Japan). Briefly, $20 \mu \mathrm{L}$ of each sample of aqueous solution at a concentration of $1 \mathrm{mg} / \mathrm{mL}$ was added to $20 \mu \mathrm{L}$ of substrate and $20 \mu \mathrm{L}$ of an enzyme working solution in triplicate. Captopril@ was used as a positive control at a concentration of $0.05 \mu \mathrm{M}$, as recommended by the manufacturer. The samples were incubated at $37^{\circ} \mathrm{C}$ for $1 \mathrm{~h}$. A $200 \mu \mathrm{L}$ indicator working solution was then added to each well, and subsequent incubation at room temperature was carried out for $10 \mathrm{~min}$. The absorbance at $450 \mathrm{~nm}$ was read using a FLUOstarOmega microplate reader (BMG LABTECH GmbH, Offenburg, Germany). The percentage of inhibition was calculated using the following equation:

$$
\text { ACE-I Inhibition }(\%)=\left(\left(\mathrm{A}_{0}-\mathrm{A}_{\mathrm{I}}\right) / \mathrm{A}_{0}\right) \times 100 \%
$$


where $A_{0}$ is the substrate absorbance at $450 \mathrm{~nm}$ in the presence of ACE-I and absence of the inhibitor and $A_{I}$ is the substrate absorbance at $450 \mathrm{~nm}$ in the presence of ACE-I and the inhibitor or Captopril@ (positive control).

Protein isolates from the microalgae were tested in vitro for renin inhibition activity. The renin inhibition screening assay (Cambridge Biosciences, Cambridge, UK) was carried out as per the manufacturer's instructions. Briefly, $10 \mu \mathrm{L}$ of each sample of the inhibitor or renin-positive control Z-Arg-Arg-Pro-Phe-His-Sta-Ile-His-Lys-(Boc)-OMe at a concentration of $1 \mathrm{mg} / \mathrm{mL}$ dimethyl sulfoxide (DMSO) was added independently to the $20 \mu \mathrm{L}$ renin substrate, $150 \mu \mathrm{L}$ assay buffer and $10 \mu \mathrm{L}$ renin in triplicate. The samples were incubated at $37^{\circ} \mathrm{C}$ for $15 \mathrm{~min}$ and read with excitation wavelengths of $340 \mathrm{~nm}$ and emission wavelengths of $500 \mathrm{~nm}$. The fluorescence was read using a FLUOstar Omega microplate reader (BMG LABTECH GmbH, Offenburg, Germany). The percentage of inhibition was calculated using the following equation:

$$
\text { Renin Inhibition }(\%)=\left(\left(\mathrm{A}_{0}-\mathrm{A}_{\mathrm{I}}\right) / \mathrm{A}_{0}\right) \times 100 \%
$$

where $A_{0}$ is the substrate florescence in the presence of renin and absence of the inhibitor and $A_{I}$ is the substrate florescence in the presence of renin and the inhibitor or control (ZArg-Arg-Pro-Phe-His-Sta-Ile-His-Lys-(Boc)-OMe, (Sigma-Aldrich, Steinheim, Germany)).

\subsection{Statistical Analysis}

All measurements were carried out in triplicate $(n=3)$. Statistical analysis was performed using Excel 2010. The differences in solubility and foaming capacity at different $\mathrm{pH}$ values were analyzed using one-way ANOVA and a post-hoc Tukey's HSD test. In all cases, the criterion for statistical significance was $p<0.05$.

\section{Results and Discussion}

\subsection{Protein Yield and Composition}

The protein contents of the generated extracts isolated from Spirulina platensis and Isochrysis galbana T-Iso were calculated, and the results are shown in Table 1 . The extracts contained $85.50 \pm 4.90 \%$ and $71.90 \pm 8.60 \%$ protein, respectively. The Spirulina sp. and Isochrysis sp. extracts contained $3.27 \pm 4.90 \%$ and $2.87 \pm 1.27 \%$ lipid and consisted of $2.10 \pm 0.40 \%$ and $1.70 \pm 1.10 \%$ ash, respectively. The quantity of extractable protein was $17.15 \pm 1.5 \mathrm{~g}$ protein/100 g from the Spirulina sp. biomass and $23.18 \pm 10.60 \mathrm{~g}$ protein $/ 100 \mathrm{~g}$ biomass from the Isochrysis sp. biomass, respectively, using the traditional extraction method. These results are lower than the protein yields described in previous studies, which reported the level of protein obtainable from Spirulina platensis to be $55-77 \%$ of the dry weight of the alga. This may be due to the method used to cultivate Spirulina sp. and Isochrysis sp. for use in this work. It may also be due to a different nitrogen conversion factor being used in previous calculations, which resulted in a higher estimation of protein in these studies. It is well documented that protein measurement methods can yield very different results [21-23]. In addition, the use of sonication to burst the cell wall may have involved a probe instead of a sonication bath, as used in this work.

\subsection{Amino Acid Composition}

The total amino acid compositions of the Spirulina sp. protein extract and Isochrysis sp. protein extract are shown in Table 1. The total amino acid contents of the whole Spirulina sp. and Spirulina sp. protein extracts were determined to be $314.71 \mathrm{~g} / \mathrm{kg}$ DW and $380.99 \mathrm{~g} / \mathrm{kg}$ DW, respectively, and the total amino acid contents of Isochrysis sp. and the protein extracts were determined to be $257.06 \mathrm{~g} / \mathrm{kg}$ DW and $22.20 \mathrm{~g} / \mathrm{kg}$ DW, respectively, with the essential amino acid composition of approximately $40.93 \%$ of the total amino acid composition for Spirulina sp. and $45.18 \%$ for the Spirulina protein extract. The essential amino acid composition for the Isochrysis sp. and Isochrysis sp. protein extracts were $43.55 \%$ and $42.03 \%$ of the total amino acid composition, respectively, and were comparable to other reports [24]. The level of the essential amino acids lysine and methionine con- 
tained in both the soluble protein extracts were $14.26 \mu \mathrm{g} / \mathrm{mL}$ and $9.08 \mu \mathrm{g} / \mathrm{mL}$ of lysine, respectively, for the Spirulina sp. soluble protein extract and Isochrysis sp. soluble protein extract and $0.913 \mu \mathrm{g} / \mathrm{mL}$ and $0.57 \mu \mathrm{g} / \mathrm{mL}$ of methionine, respectively. The Spirulina sp. soluble protein extracts contained less methionine and lysine than previously reported by Liestianty et al. [25], who reported methionine and lysine contents of $14 \mathrm{mg} \mathrm{g}^{-1}$ (methionine) and $30 \mathrm{mg} \mathrm{g}^{-1}$ (lysine). The free amino acid contents of both microalga protein extracts are shown in Table 2.

Table 1. Proximate analysis and total amino acid content of the microalgal protein extracts.

\begin{tabular}{|c|c|c|c|c|c|}
\hline & & Spirulina sp. & & Isochrysis sp. & \\
\hline & & $\begin{array}{c}\text { Spirulina platensis } \\
\text { Whole Biomass } \\
\text { (g/kg) }\end{array}$ & $\begin{array}{c}\text { Spirulina platensis } \\
\text { Protein Extract } \\
\text { (g/kg) }\end{array}$ & $\begin{array}{c}\text { Isochrysis T-Iso } \\
\text { Whole Biomass (g/ } \\
\text { kg) }\end{array}$ & $\begin{array}{c}\text { Isochrysis T-Iso } \\
\text { Protein Extract } \\
\text { (g/kg) }\end{array}$ \\
\hline \multirow{3}{*}{$\begin{array}{l}\text { Essential amino } \\
\text { acids }\end{array}$} & Isoleucine & 3.53 & 4.61 & 2.75 & 0.3 \\
\hline & $\begin{array}{l}\text { Leucine } \\
\text { Valine } \\
\text { Phenylanine } \\
\text { Tyrptophan }\end{array}$ & $\begin{array}{l}5.59 \\
4.54 \\
2.95\end{array}$ & $\begin{array}{l}7.58 \\
5.46 \\
4.38\end{array}$ & $\begin{array}{l}5.39 \\
3.64 \\
3.07\end{array}$ & $\begin{array}{c}0.45 \\
0.4 \\
0.3\end{array}$ \\
\hline & $\begin{array}{l}\text { Histidine } \\
\text { Lysine } \\
\text { Threonine } \\
\text { Methionine }\end{array}$ & $\begin{array}{l}1.48 \\
2.78 \\
3.38 \\
1.84\end{array}$ & $\begin{array}{c}1.82 \\
2.64 \\
3.58 \\
1.9\end{array}$ & $\begin{array}{l}2.53 \\
2.8 \\
3.13 \\
1.95\end{array}$ & $\begin{array}{l}0.59 \\
0.27 \\
0.31 \\
0.17\end{array}$ \\
\hline \multirow{5}{*}{$\begin{array}{l}\text { Non-essential } \\
\text { amino acids }\end{array}$} & Alanine & 5.38 & 5 & 4.88 & 0.54 \\
\hline & $\begin{array}{l}\text { Glycine } \\
\text { Proline } \\
\text { Tyrosine }\end{array}$ & $\begin{array}{l}3.28 \\
2.35 \\
2.41\end{array}$ & $\begin{array}{l}4.11 \\
3.38 \\
2.75\end{array}$ & $\begin{array}{l}3.46 \\
3.17 \\
0.98\end{array}$ & $\begin{array}{l}0.36 \\
0.38\end{array}$ \\
\hline & $\begin{array}{l}\text { Aspartic acid and } \\
\text { Asparagine }\end{array}$ & 6.55 & 7.18 & 5.92 & 0.72 \\
\hline & $\begin{array}{l}\text { Glutamic acid and } \\
\text { Glutamine }\end{array}$ & 8.99 & 7.65 & 6.43 & 0.73 \\
\hline & $\begin{array}{l}\text { Arginine } \\
\text { Serine } \\
\text { Cysteine }\end{array}$ & $\begin{array}{l}4.09 \\
3.06 \\
1.56\end{array}$ & $\begin{array}{l}4.31 \\
3.63 \\
0.69\end{array}$ & $\begin{array}{l}3.61 \\
2.72 \\
1.55\end{array}$ & $\begin{array}{l}0.38 \\
0.27 \\
0.48\end{array}$ \\
\hline $\begin{array}{c}\text { Total amino acids } \\
\text { (TAA) }\end{array}$ & & 63.76 & 70.67 & 57.98 & 6.65 \\
\hline $\begin{array}{c}\text { Essential amino } \\
\text { acids (EAA) }\end{array}$ & & 26.09 & 31.97 & 25.26 & 2.79 \\
\hline $\begin{array}{c}\text { Non-essential } \\
\text { amino acids (NEAA) }\end{array}$ & & 47.15 & 38.7 & 32.72 & 3.86 \\
\hline $\begin{array}{l}\text { Protein } \\
\text { Ash } \\
\text { Lipid }\end{array}$ & & & $\begin{array}{c}85.5 \pm 4.9 \% \\
2.1 \pm 0.4 \% \\
3.27 \pm 4.9 \%\end{array}$ & & $\begin{array}{c}71.9 \pm 8.6 \% \\
1.7 \pm 1.1 \% \\
2.87 \pm 1.27 \%\end{array}$ \\
\hline
\end{tabular}

Table 2. Free amino acid contents of the whole alga and protein extracts.

\begin{tabular}{|c|c|c|c|c|c|}
\hline & & Spirulina sp. & & Isochrysis sp. & \\
\hline & & $\begin{array}{c}\text { Spirulina platensis } \\
\text { Whole Biomass } \\
\text { (g/kg) }\end{array}$ & $\begin{array}{c}\text { Spirulina platensis } \\
\text { Protein Extract } \\
(\mathrm{g} / \mathrm{kg})\end{array}$ & $\begin{array}{c}\text { Isochrysis T-Iso } \\
\text { Whole Biomass } \\
\text { (g/kg) }\end{array}$ & $\begin{array}{c}\text { Isochrysis T-Iso } \\
\text { Protein Extract } \\
\text { (g/kg) }\end{array}$ \\
\hline \multirow{2}{*}{$\begin{array}{l}\text { Essential amino } \\
\text { acids }\end{array}$} & Isoleucine & 10.42 & 1.84 & 12.05 & 0.45 \\
\hline & $\begin{array}{c}\text { Leucine } \\
\text { Valine } \\
\text { Phenylalanine } \\
\text { Tyrptophan } \\
\text { Histidine } \\
\text { Lysine } \\
\text { Threonine } \\
\text { Methionine }\end{array}$ & $\begin{array}{c}25.53 \\
15.2 \\
32 \\
6.73 \\
20.44 \\
8.98 \\
7.16 \\
4.92\end{array}$ & $\begin{array}{l}2.31 \\
1.96 \\
2.63 \\
. \\
1.53 \\
0.13 \\
0.94 \\
.\end{array}$ & $\begin{array}{c}17.63 \\
15.86 \\
12.3 \\
15.79 \\
7.12 \\
4.54 \\
16.91 \\
2.51\end{array}$ & $\begin{array}{c}0.55 \\
1.05 \\
0.54 \\
. \\
0.69 \\
. .64 \\
.\end{array}$ \\
\hline \multirow{5}{*}{$\begin{array}{l}\text { Non-essential } \\
\text { amino acids }\end{array}$} & Alanine & 24.37 & 1.33 & 50.88 & 1.84 \\
\hline & $\begin{array}{l}\text { Glycine } \\
\text { Proline } \\
\text { Tyrosine }\end{array}$ & $\begin{array}{c}3.92 \\
1.14 \\
29.55\end{array}$ & $\begin{array}{l}0.55 \\
0.22 \\
2.81\end{array}$ & $\begin{array}{l}12.45 \\
18.32 \\
12.01\end{array}$ & $\begin{array}{l}0.14 \\
0 . \dot{4} 5\end{array}$ \\
\hline & $\begin{array}{c}\text { Aspartic acid and } \\
\text { Asparagine }\end{array}$ & 6.08 & 1.08 & 7.43 & 0.69 \\
\hline & $\begin{array}{l}\text { Glutamic acid and } \\
\text { Glutamine }\end{array}$ & 54.79 & 2 & 11.01 & 0.89 \\
\hline & $\begin{array}{l}\text { Arginine } \\
\text { Serine } \\
\text { Cysteine }\end{array}$ & $\begin{array}{l}15.12 \\
8.65 \\
17.18\end{array}$ & $\begin{array}{l}1.79 \\
0.56 \\
2.51\end{array}$ & $\begin{array}{c}20.98 \\
10.14 \\
6.19\end{array}$ & $\begin{array}{l}0.59 \\
1.16\end{array}$ \\
\hline $\begin{array}{l}\text { Total free amino } \\
\text { acids (FAA) }\end{array}$ & & 292.18 & 24.19 & 254.12 & 9.68 \\
\hline $\begin{array}{l}\text { EAA } \\
\text { NEAA }\end{array}$ & & $\begin{array}{c}131.38 \\
160.8\end{array}$ & $\begin{array}{l}11.34 \\
12.85\end{array}$ & $\begin{array}{l}104.71 \\
149.41\end{array}$ & $\begin{array}{l}3.92 \\
5.76\end{array}$ \\
\hline
\end{tabular}


The protein content of the Spirulina sp. Extract, in terms of TAA and FAAs, was greater following extraction than that of Isochrysis sp., despite the fact that both whole microalgae have similar total and free amino acid profiles. Both microalgae contained a greater percentage of FAA $(292.18 \mathrm{~g} / \mathrm{kg}$ and $254.12 \mathrm{~g} / \mathrm{kg}$ for the Spirulina $\mathrm{sp}$. and Isochrysis sp., respectively) than TAAs $(63.76 \mathrm{~g} / \mathrm{kg}$ and $57.98 \mathrm{~g} / \mathrm{kg}$ for Spirulina sp. and Isochrysis sp. respectively). The extraction process increased the TAA content of the Spirulina sp. protein extract, but the Isochrysis sp. protein extract contained less than $10 \%$ of the available TAA in this microalga. The Isochrysis T-Iso species does not contain a cell wall. The protein extraction process used was not suitable for this species, and this warrants further investigation. The yield of protein obtained from Isochrysis sp. in this study was similar to that achieved previously with pressurized liquid extraction using water, where approximately $18 \%$ of the protein was recovered [25]. Furthermore, there were inconsistencies observed between the determined protein content (\% values) and the TAA content for the two extracts. Both contained $>70 \%$ protein (i.e., $>700 \mathrm{~g} / \mathrm{kg}$ ), but the total AA content was 7\% (i.e., $70 \mathrm{~g} / \mathrm{kg}$ ). Therefore, for Spirulina sp., the discrepancy was a factor of 12, while for Isochrysis sp., it was a factor of 108. This may be due in part to the protein determination method used and discussed and the nitrogen conversion factor used.

\subsection{Determination of $\mathrm{pH}$ and Water Activity of Protein Extracts}

The water activity $\left(\mathrm{a}_{\mathrm{w}}\right)$ values of the protein extracts generated from Spirulina sp. and Isochrysis sp. were determined to be $0.431 \pm 0.01$ and $0.389 \pm 0.03$, respectively, when measured at $22.4^{\circ} \mathrm{C} \pm 0.78{ }^{\circ} \mathrm{C}$. The water activity values observed for the protein extracts would not permit the growth of microbes (yeasts, molds, spoilage bacteria or fungi), as they are below 0.45 . The protein extracts can therefore be considered stable and should not support microbial growth. The $\mathrm{pH}$ values of the Spirulina sp. protein extract and Isochrysis sp. protein extract were determined to be $4.25 \pm 0.00$ and $4.29 \pm 0.05$, respectively. Both of these physicochemical characteristics are important for the storage of any food product before further use in industry. Foods with a high $a_{w}$ value show rapid deterioration due to biological and chemical changes, due to the fact that $\mathrm{a}_{\mathrm{w}}$ influences microbial growth, lipid oxidation and enzymatic activities in foods $[26,27]$. The $\mathrm{pH}$ values of both protein extracts are comparable to those of protein extracts reported previously from the brown macroalga Himanthalia elongata [9], which has a $\mathrm{pH}$ value of $3.99 \pm 0.02$. The water activities identified for the Spirulina sp. and Isochrysis sp. protein extracts were similar to those of sliced almonds, which have a reported $\mathrm{a}_{\mathrm{w}}$ of 0.476 at $20^{\circ} \mathrm{C}$ [19].

\subsection{Foaming Capacity and Stability of Protein Extracts}

The foaming capacity and stability of proteins can have a sensory and flavor impact on food formulations and can improve the smoothness, lightness and palatability of the food product [28]. The foaming capacity and stability profiles of the protein extracts generated from Spirulina sp. and Isochrysis sp. were compared at different $\mathrm{pH}$ values to the foaming capacity and stability of flaxseed and whey protein isolates in triplicate (Figure 1). The foams formed for the microalgal protein extracts were most stable at $\mathrm{pH} 2$ and $\mathrm{pH} 4$. Otherwise, the $\mathrm{pH}$ level had little effect on the foaming stability.

\subsection{The WHC and OHC of Protein Extracts}

The hydration characteristics of food are very important for effective digestion to occur and can be defined by the swelling capacity, solubility, WHC and other characteristics. The WHC of a food product describes the ability to hold water within the food matrix [29]. Furthermore, the WHC of foods such as meat relates to quality attributes, which influence product yield and have economic implications but is also important in terms of eating quality [30]. The WHC and OHC of the protein extracts generated from Spirulina sp. and Isochrysis sp. were compared to those of a whey protein isolate and flaxseed protein, respectively (Figure 2). The WHC values for the protein extracts generated from Spirulina sp. and Isochrysis sp. were $2.25 \mathrm{~g}$ water/g protein extract and $0.47 \mathrm{~g}$ water/g 
protein extract, respectively, compared with a WHC of $6.39 \mathrm{~g}$ water/g defatted flaxseed protein. Previously, De Moor and Huyghebaert [30] reported that the overall water-holding capacities of whey powders and demineralized whey powders are generally low, and this is what we observed in this study. These WHC values were lower than those reported previously for seaweed-derived protein extracts, including Himanthalia elongata (WHC value of $10.27 \pm 0.09 \mathrm{~g}$ water $/ \mathrm{g}$ protein) [9]. The WHC obtained for the Spirulina sp. protein extract (2.25 g water/g protein) was similar to that derived from Kappaphycus alvarezii, which had a reported WHC of $2.22 \pm 0.04 \mathrm{~g}$ water/g protein [31]. High WHC values are required for viscous foods including custards, sausages, doughs and baked products, as they help to provide thickening and viscosity to the foods [32]. The WHC values observed for both algal protein extracts were lower in WHC value than the H. elongata proteins [9]. The solubility values observed for both protein extracts at $\mathrm{pH} 4$ and 2, respectively, might be because the proteins have their isoelectric point at these $\mathrm{pH}$ values, and at more acidic or alkaline $\mathrm{pH}$ values, the protein will acquire a net positive or negative charge.
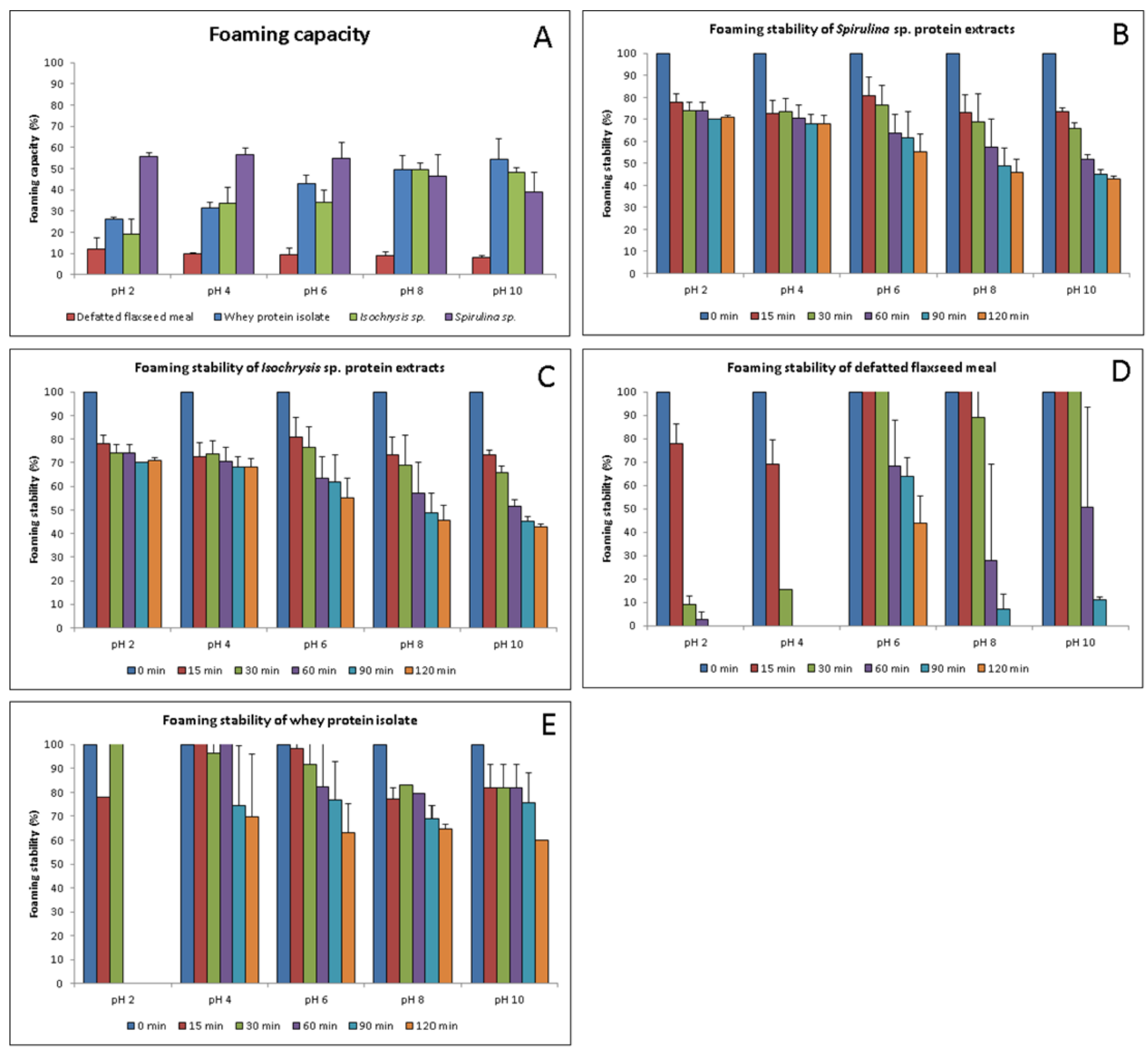

Figure 1. Foaming capacity (A), as well as foaming stability of Spirulina sp. (B), Isochrysis sp. (C), flaxseed meal (D) and whey protein isolate $(\mathbf{E})(\mathrm{n}=3)$. 


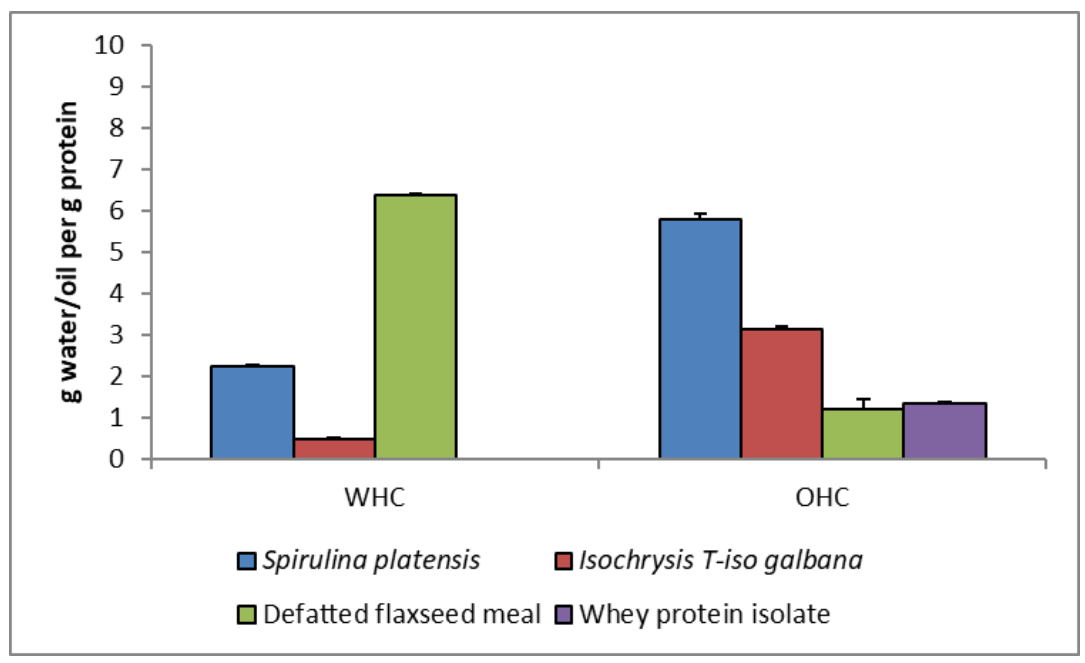

Figure 2. Oil and water holding capacity of microalgal protein extracts compared with the controls $(n=3)$.

The microalgal protein extracts had greater OHCs than the whey protein isolate and flaxseed protein analyzed. A high OHC value is desirable in food manufacturing for the retention of flavor and improved palatability. The OHC of the Spirulina sp. protein extract was $5.80 \mathrm{~g}$ oil/g protein extract, and the $\mathrm{OHC}$ for the Isochrysis sp. protein extract was $3.16 \mathrm{~g}$ oil $/ \mathrm{g}$ protein extract, compared with $1.23 \mathrm{~g}$ oil/g defatted flaxseed protein extract and $\sim 1 \mathrm{~g}$ oil/g whey protein isolate. These $\mathrm{OHC}$ values compare favorably to other protein isolates, including the seaweed H. elongata protein concentrate, which reported an OHC of $8.1 \mathrm{~g}$ oil/g protein extract [9]. The macroalgal protein powder Kapparazii powder ${ }^{\mathrm{TM}}$ had an $\mathrm{OHC}$ value of $0.20 \mathrm{~g} / \mathrm{g}$, and rice bran protein concentrates have reported $\mathrm{OHC}$ values of between 3.74 and $9.18 \mathrm{~g}$ oil/g [29].

\subsection{Molecular Weight Distribution Profile of Soluble Proteins Only from Spirulina sp. and Isochrysis $\mathrm{sp}$.}

The molecular weight distribution profiles of the soluble protein extracts generated from Spirulina sp. and Isochrysis sp. are shown in Figure 3A,B. The profiles varied between the two microalgae, with the largest percentage of proteins in the Spirulina sp. extract found in the $>100 \mathrm{kDa}$ fraction $(62.28 \%)$. However, this fraction, in fact, not only contained $>100 \mathrm{kDa}$ proteins, as seen by the appearance and distribution (Gel A). A lot of the content was found in the lower part of the gel, indicating a MW far less than $100 \mathrm{kDa}$. It also contained protein $>100 \mathrm{kDa}$. Based on the SDS-PAGE of the individual fraction, the protein in the individual fractions did not have the overall characteristics (i.e., sharp size distribution) intended. Furthermore, when considering the whole extract, the content of high MW protein $(>100 \mathrm{kDa}$ ) did not appear to be as high as what was determined by the fraction of dry mass. This calls into question the efficiency of the fractionation and that it may not have worked as intended. Size exclusion chromatography could also be used to determine the size range of the extracts. This is in contrast to the protein extract generated for Isochrysis sp., where $70.54 \%$ of the proteins were low molecular weight proteins. The large percentage of proteins that were of a low molecular weight in size (less than $3 \mathrm{kDa}$ ) in the Isochrysis sp. protein extract was positive in terms of the functional food applications of this protein, as it is well known that peptides and proteins less than $3 \mathrm{kDa}$ in size can be bioactive in nature and may have health-beneficial effects for the consumer $[33,34]$. However, this might also indicate that the traditional extraction method is not suitable for use with Isochrysis sp., as less than $10 \%$ of the total amino acids found in the dry microalgae were extracted and found in the soluble protein extract. Similar results were shown in a recent study where traditional protein aqueous extraction was applied to the seaweed Eucheuna denticulatum [35]. 


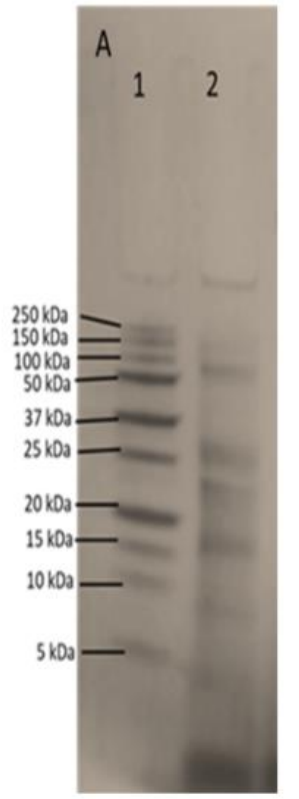

Lane 1; High MW marker, Lane 2; Whole Spirulina sp., traditional extract protein,

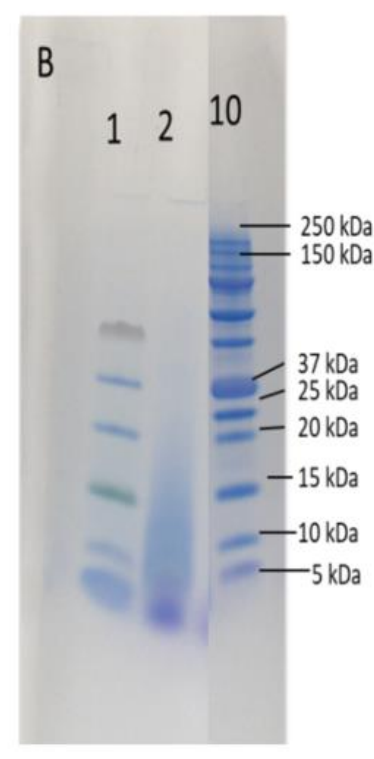

Lane 1; Molecular weight marker; Lane 2: Isochrysis protein traditional extract:

Figure 3. Tris-Tricine SDS-PAGE, performed using a Mini-PROTEAN ${ }^{\circledR}$ electrophoresis unit using Mini-PROTEAN ${ }^{\circledR} 10-20 \%$ Tris-Tricine precast gels (Bio-Rad laboratories, USA) for Spirulina sp. protein extract (A) and Isochrysis sp. protein extract (B).

\subsection{Solubility of Protein Extracts}

The solubilities of the microalgal protein extracts were assessed at $\mathrm{pH}$ values varying from 2 to 12 at concentrations of $1 \% w / v$ in water (Figure 4). The $\mathrm{pH}$ had a significant influence on the solubilities of both microalgal protein extracts. The minimum solubility was observed at $\mathrm{pH} 4(4.99 \%)$, rising to $32.44 \%$ at $\mathrm{pH} 10$, with the maximum solubility of the Spirulina sp. protein extract observed at pH $12(62.99 \%)$. The minimum solubility value observed for the Isochrysis sp. protein extract was at $\mathrm{pH} 2(14.12 \%)$, with a maximum solubility at $1 \% w / v$ observed at $\mathrm{pH} 12(19.25 \%)$. The maximum solubility values for both whey and defatted flaxseed protein were also observed at $\mathrm{pH} 12$, with solubility values of $100 \%$ and $87 \%$, respectively, observed for these proteins when tested at $\mathrm{pH} 12$ at a concentration of $1 \% w / v$ water.

\subsection{Emulsion Activity and Stability of Protein Extracts}

The emulsion activity and stability of the protein extracts generated from Spirulina $\mathrm{sp}$. and Isochrysis sp. at five different $\mathrm{pH}$ values using four different oils are shown in Figure 6. The Spirulina sp. protein extract suspended in olive oil showed the highest emulsion activity $(22.41 \%)$, and rapeseed oil showed the lowest $(21.00 \%)$. The Isochrysis sp. protein extract suspended in olive oil showed the highest emulsion activity $(11.36 \%)$, and rapeseed oil showed the lowest $(10.01 \%)$. Both microalgal protein extracts displayed poor emulsion activity and stability percentage values compared with the commercial controls of defatted flaxseed protein and whey protein isolate (Figure 5). However, the Spirulina sp. protein extract did display excellent emulsion stability values $(85.91 \%)$ when assessed in olive oil. The EA values obtained here are in contrast to results reporting the EA values of seaweed derived protein extracts in oils (75.68-99.67\%). In general, emulsion stability was more effective in the olive and groundnut oils. Emulsion stability can be affected by several factors, including the $\mathrm{pH}$, droplet size, net charge, interfacial tension, viscosity and protein conformation. The high emulsion stability observed previously for the Spirulina sp. protein extract in olive oil after heating at $85^{\circ} \mathrm{C}$ could be due to the dissociation of some proteins, resulting in the formation of subunits with more hydrophobic groups and stronger interactions with the lipid phase [36]. 


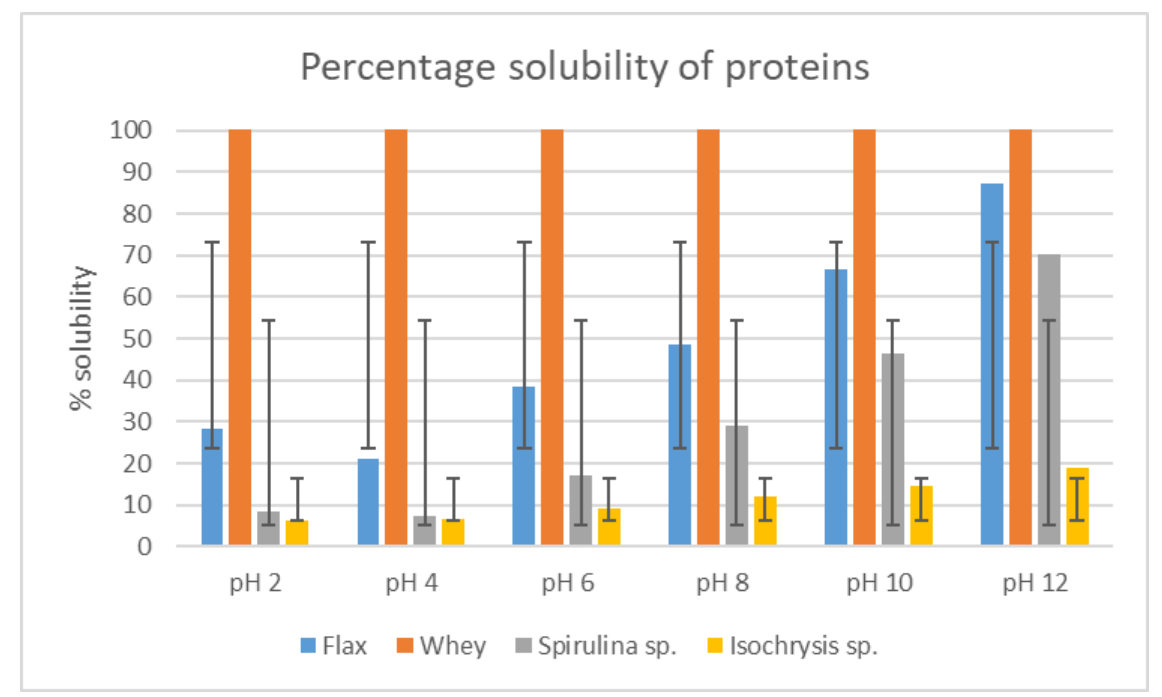

Figure 4. Solubility of extracted proteins at different $\mathrm{pH}$ values $(\mathrm{n}=3)$.

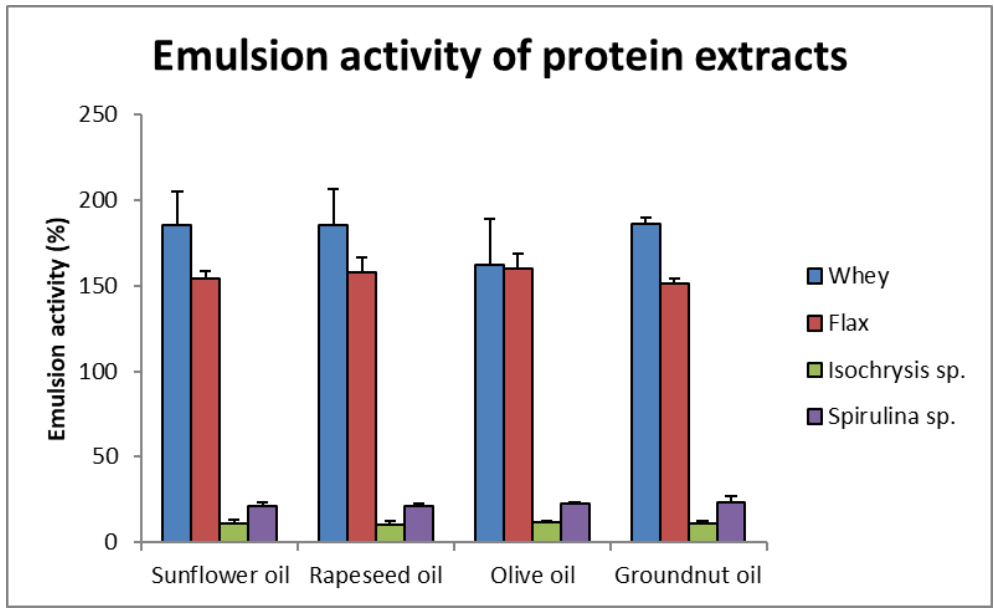

(A)

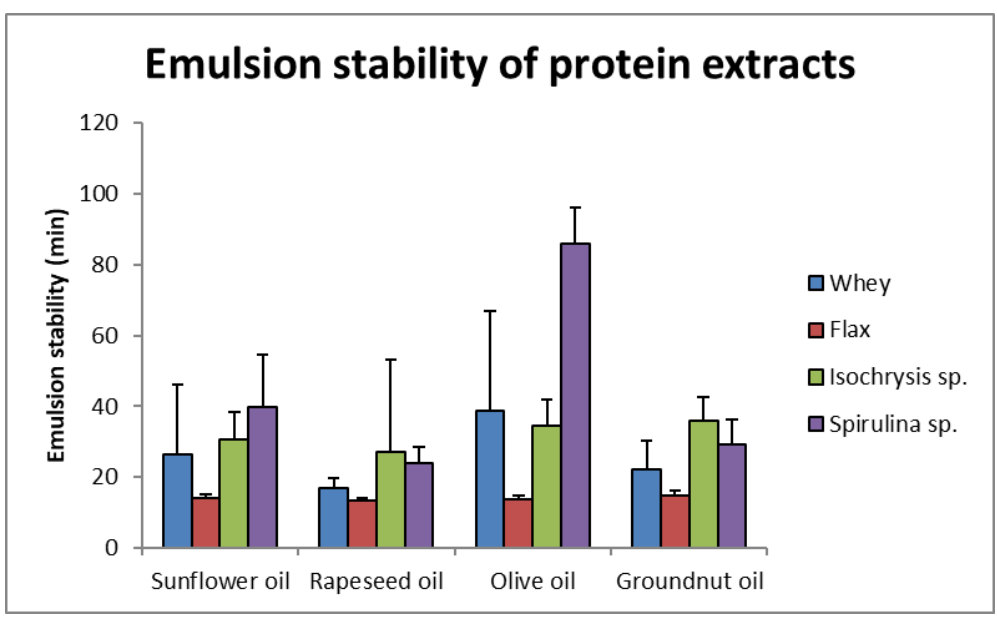

(B)

Figure 5. ES (A) and EA (B) of soluble protein extracts $(n=3)$. Values calculated against whey. 


\subsection{ACE-I and Renin Inhibitory Activities}

The microalgal protein extracts displayed renin inhibition values ranging between $23.18 \%( \pm 2.16 \%)$ and $25 \%( \pm 7.7 \%)$ (Figure 6$)$ for the Isochrysis sp. and Spirulina sp. protein extracts, respectively. The Isochryis sp. protein extract inhibited ACE-I by $95.34 \%$ compared with the Spirulina protein extract, which inhibited ACE-I by $91.04 \%$ when assayed at a concentration of $1 \mathrm{mg} / \mathrm{mL}$ compared with the control Captopril ${ }^{\circledR}$. There was significantly lower renin inhibition activity compared with ACE-I inhibitory activity. The characteristics of renin inhibitory peptides are not as well defined as other bioactive peptide targets (such as ACE-I inhibitory peptides) $[25,36]$.

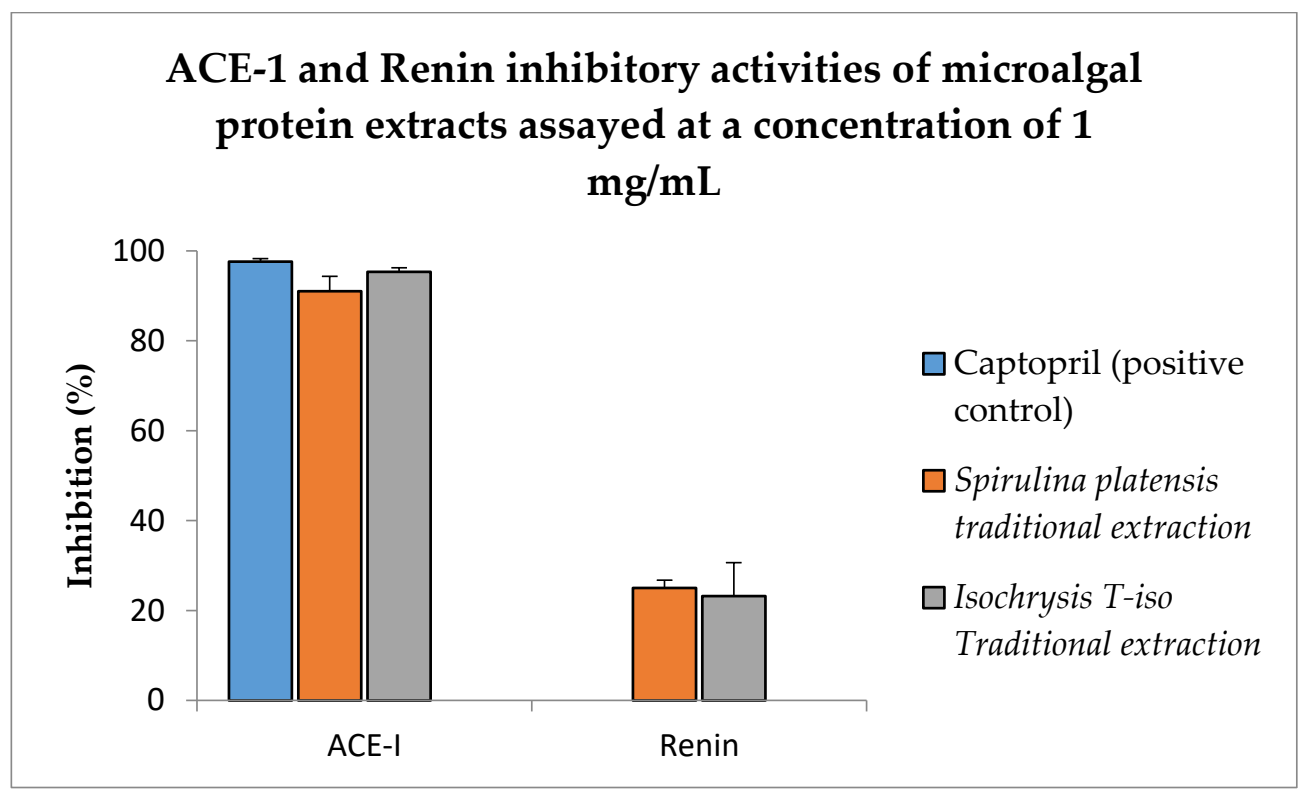

Figure 6. ACE-I and renin inhibitory activities of proteins extracted from Spirulina sp. and Isochrysis galbana T-Iso, assayed at a concentration of $1 \mathrm{mg} / \mathrm{mL}$ compared with the control (Captopril@) $(\mathrm{n}=3)$ and $10 \mu \mathrm{M}$ Z-Arg-Arg-Pro-Phe-His-Sta-Ile-His-Lys-(Boc)-OMe (renin inhibitor).

\section{Conclusions}

The foaming capacity and stability values observed for both microalgal protein extracts, along with their solubility at $\mathrm{pH} 10-12$ and excellent $\mathrm{OHC}$ values, suggest that these proteins could be used in the formulation of a wide variety of foods with alkaline $\mathrm{pH}$ values and with an oil consistency such as that in green drinks with a $\mathrm{pH}$ greater than 9.5 and tomato juices. Based on the FC and FS, the microalgal extracts have good stability independent of the $\mathrm{pH}$ value compared with flaxseed. However, the aqueous solubility of the extracts limits applications. The renin-angiotensin-aldosterone system (RAAS) controls hypertension development through the actions of two enzymes: renin (EC 3.4.23.15) and ACE-I (EC 3.4.15.1). In a previous study, the response surface methodology (RSM) was used to generate hydrolysates with ACE-I inhibitory activities from Isochrysis galbana (not Spirulina sp.). The conditions that produced the greatest ACE-I inhibitory activity were a temperature of $55.64^{\circ} \mathrm{C}$, a substrate concentration of $5.46 \mathrm{~g}(100 \mathrm{~mL})^{-1}$ and a trypsin enzyme/substrate ratio (E/S) of $6.27 \%$ [37]. The highest ACE inhibitory activity observed was $47.62 \%$ ACE-I inhibition at a concentration of $1 \mathrm{mg} / \mathrm{mL}$ [33]. The ACE-I inhibitory values observed in this study (95\%) were greater than $47.62 \%$ at a concentration of $1 \mathrm{mg} / \mathrm{mL}$ compared with Captopril@, the positive control which was assayed at a concentration of $0.05 \mathrm{mg} / \mathrm{mL}$. The renin inhibitory control was also assayed at the same concentration. In addition, the protein extracts generated were found to inhibit renin [38]. In addition, the observed ACE-I and renin inhibitory activities shown by the protein extracts suggest that they could find applications in functional foods for preventative healthcare. Spirulina is certified as generally recognized as safe (GRAS) - GRN No. 127—by the United States 
(US) Food and Drug Administration (FDA) and complies with the requirements for use set out by Regulation (EU) 2015/2283 on novel foods [25]. However, the presence of contaminants and anti-nutritional factors as well as allergens should be evaluated as discussed previously. The bioaccessibility and bioavailability of the ACE-I inhibitory activities should be characterized, especially when these ingredients are incorporated in different food matrices, a driving factor of such important nutritional and health benefits [38]. This data is essential for preventative or adjuvant therapeutic strategies against high blood pressure and associated diseases.

Author Contributions: Conceptualization, S.B. and M.H.; methodology, S.B.; writing—original draft preparation, S.B.; writing-review and editing, M.H.; supervision, M.H.; project administration, M.H.; funding acquisition, M.H. Both authors have read and agreed to the published version of the manuscript.

Funding: Teagasc grant number NFNY-6889-142 funded this research.

Institutional Review Board Statement: Not applicable.

Informed Consent Statement: Not applicable.

Data Availability Statement: Not applicable.

Acknowledgments: This project was carried out as part of the BioAlgae Project (Teagasc funded project no. 2016-073). Stephen Bleakley is in receipt of a PhD Walsh Fellowship (grant no. NFNY 6889-142) funded by Teagasc for the period of 2016-2020. The authors would also like to acknowledge the EUALGAE COST Action-European Network for algal bioproducts ES1408.

Conflicts of Interest: The authors declare no conflict of interest.

\section{References}

1. Moorehead, K.; Campelli, B. Spirulina Nature's Superfood, 3rd ed.; Cyanotech Corporation: Kalulua-Kona, HI, USA, 2011.

2. Dörner, J.; Carbonell, P.; Pino, S.; Farías, A. Variation of Fatty Acids in Isochrysis galbana (T-Iso) and Tetraselmis suecica, cultured under different Nitrate availabilities. Fish Aquac. J. 2014, 5, 106. [CrossRef]

3. Barka, A.; Blecker, C. Microalgae as a potential source of single cell proteins. A review. Biotechnol. Agron. Soc. Environ. 2016, 20, 427436.

4. Gouveia, L.; Batista, A.P.; Sousa, I.; Raymundo, A.; Bandarra, N.M. Microalgae in novel food products. In Food Chemistry Research Developments; Papadopoulos, K.N., Ed.; Nova Science Publishers, Inc.: New York, NY, USA, 2008; pp. 75-111.

5. Piwowar, A.; Harasym, A. The importance and prospects of the use of algae in Agribusiness. Sustainability 2020, $12,5669$. [CrossRef]

6. Sankaran, R.; Manickam, S.; Yap, Y.J.; Ling, T.C.; Chang, J.-S.; Show, P.L. Extraction of proteins from microalgae using integrated method of sugaring-out assisted liquid biphasic flotation (LBF) and ultrasound. Ultrason. Sonochem. 2018, 48, 231-239. [CrossRef] [PubMed]

7. Gerde, J.A.; Montalbo-Lomboy, M.; Yao, L.; Grewell, D.; Wang, T. Evaluation of microalgae cell disruption by ultrasonic treatment. Bioresour. Technol. 2012, 125, 175-181. [CrossRef]

8. Safi, C.; Charton, M.; Ursu, A.V.; Laroche, C.; Zebib, B.; Pontalier, P.-Y.; Vaca-Garcia, C. Release of hydro-soluble microalgal proteins using mechanical and chemical treatments. Algal Res. 2014, 3, 55-60. [CrossRef]

9. Garcia-Vaquero, M.; Lopez-Alonso, M.; Hayes, M. Assessment of the functional properties of protein extracted from the brown seaweed Himanthalia elongata (Linnaeus) S. F. Gray. Food Res. Int. 2017, 99, 971-978. [CrossRef]

10. Hamed, I. The Evolution and Versatility of Microalgal Biotechnology: A Review. Compr. Rev. Food Sci. Food Saf. 2016, 15, 1104-1123. [CrossRef] [PubMed]

11. Galland-Irmouli, A.-V.; Fleurence, J.; Lamghari, R.; Luçon, M.; Rouxel, C.; Barbaroux, O.; Bronowicki, J.-P.; Villaume, C.; Guéant, J.-L. Nutritional value of proteins from edible seaweed Palmaria palmata (dulse). J. Nutr. Biochem. 1999, 10, 353-359. [CrossRef]

12. Fitzgerald, C.; Mora, L.; Gallagher, E.; O'Connor, P.; Prieto, J.; Vila, A.; Hayes, M. Isolation and characterisation of bioactive pro-peptides with in vitro renin inhibitory activities from the macroalga Palmaria palmata. J. Agric. Food Chem. 2012, 60, 10. [CrossRef]

13. Dave, L.A.; Hayes, M.; Mora, L.; Montoya, C.A.; Moughan, P.J.; Rutherfurd, S.M. Gastrointestinal Endogenous Protein-Derived Bioactive Peptides: An in Vitro Study of Their Gut Modulatory Potential. Int. J. Mol. Sci. 2016, 17, 482. [CrossRef] [PubMed]

14. Simonne, A.H.; Simonne, E.H.; Eitenmiller, R.R.; Mills, H.A.; Cresman, C.P. Could the Dumas Method Replace the Kjeldahl Digestion for Nitrogen and Crude Protein Determinations in Foods? J. Sci. Food Agric. 1997, 73, 39-45. [CrossRef]

15. Lourenço, S.O.; Barbarino, E.; Lavín, P.L.; Lanfer Marquez, U.M.; Aidar, E. Distribution of intracellular nitrogen in marine microalgae. Calculation of new N-P conversion factors. Eur. J. Phycol. 2002, 37, 758-811. 
16. Hill, R.L. Hydrolysis of proteins. Adv. Protein Chem. 1965, 20, 37.

17. Bencini, M.C. Functional Properties of Drum-Dried Chickpea (Cicer arietinum L.) Flours. J. Food Sci. 1986, 51, 1518-1521. [CrossRef]

18. Beuchat, L.R.; Cherry, J.P.; Quinn, M.R. Physicochemical properties of peanut flour as affected by proteolysis. J. Agric. Food Chem. 1975, 23, 616-620. [CrossRef]

19. Poole, S.; West, S.I.; Walters, C.L. Protein-protein interactions: Their importance in the foaming of heterogeneous protein systems. J. Sci. Food Agric. 1984, 35, 701-711. [CrossRef]

20. Pearce, K.N.; Kinsella, J.E. Emulsifying properties of proteins: Evaluation of a turbidimetric technique. J. Agric. Food Chem. 1978, 26, 716-723. [CrossRef]

21. Ufaz, S.; Galilli, G. Improving the content of essential amino acids in crop plants: Goals and opportunities. Plant Physiol. 2008, 147, 954-961. [CrossRef] [PubMed]

22. Mæhre, H.K.; Dalheim, L.; Edvinsen, G.K.; Elvevoll, E.O.; Jensen, I.-J. Protein Determination—Method Matters. Foods 2018, 7, 5. [CrossRef] [PubMed]

23. Hayes, M. Measuring Protein Content in Food: An Overview of Methods. Foods 2020, 9, 1340. [CrossRef]

24. Sablani, S.; Kasapis, S.; Rahman, M. Evaluating water activity and glass transition concepts for food stability. J. Food Eng. 2007, 78, 266-271. [CrossRef]

25. Liestianty, D.; Rodianawati, I.; Arfah, R.A.; Assa, A. Nutritional analysis of Spirulina sp to promote as superfood candidate. IOP Conf. Ser. Mater. Sci. Eng. 2015, 509, 012031. [CrossRef]

26. Schmidt, S.J.; Fontana, A.J. Appendix E: Water activity values of select food ingredients and products. In Water Activity in Foods; Blackwell Publishing Ltd.: Hoboken, NJ, USA, 2008; pp. 407-420.

27. Zayas, J. Foaming properties of proteins. In Functionality of Proteins in Food; Springer: Berlin/Heidelberg, Germany, 1997; pp. 132-227.

28. Ngoc, T.T.B.; Len, N.T.; Lindberg, J.E. Chemical characterisation and water holding capacity of Fibre-rich feedstuffs used for pigs in Vietnam. Asian Australas. J. Anim. Sci. 2012, 25, 861-868. [CrossRef]

29. Cheng, Q.; Sun, D.-W. Factors affecting the water holding capacity of red meat products: A review of recent research advances. Crit. Rev. Food Sci. Nutr. 2008, 48, 2. [CrossRef] [PubMed]

30. De Moor, H.; Huyghebaert, A. Functional properties of dehydrated protein-rich milk products. In Physico-Chemical Aspects of Dehydrated Protein-Rich Milk Products; Statens Forsoegsmejeri: Helsingor, Denmark, 1983.

31. Kumar, K.S.; Ganesan, K.; Selvaraj, K.; Rao, P.S. Studies on the functional properties of protein concentrate of Kappaphycus alvarezii (Doty) Doty-An edible seaweed. Food Chem. 2014, 153, 353-360. [CrossRef]

32. Seena, S.; Sridhar, K. Physicochemical, functional and cooking properties of under explored legumes, Canavalia of the southwest coast of India. Food Res. Int. 2005, 38, 803-814. [CrossRef]

33. Chandi, G.K.; Sogi, D. Functional properties of rich bran protein concentrates. J. Food Eng. 2007, 79, 592-597. [CrossRef]

34. Gregarsen, S.; Pertseva, M.; Marcatili, P.; Holdt, S.L.; Jacobsen, C.; García-Moreno, P.J.; Hansen, E.B.; Overgaard, M.T. Proteomic characterization of pilot scale hot-water extracts from the industrial carrageenan red seaweed Eucheuma denticulatum. bioRxiv 2020. [CrossRef]

35. Brandelli, A.; Daroit, D.J.; Corrêa, A.P.F. Whey as a source of peptides with remarkable biological activities. Food Res. Int. 2015, 73, 149-161. [CrossRef]

36. Hayes, M.; Tiwari, B.K. Bioactive Carbohydrates and Peptides in Foods: An Overview of Sources, Downstream Processing Steps and Associated Bioactivities. Int. J. Mol. Sci. 2015, 16, 22485-22508. [CrossRef] [PubMed]

37. Wu, H.; Xu, N.; Sun, X.; Yu, H.; Zhou, C. Hydrolysis and purification of ACE inhibitory peptides from the marine microalga Isochrysis galbana. J. Appl. Phycol. 2014, 27, 351-361. [CrossRef]

38. European Union. Regulation (EU) 2015/2283 of the European Parliament and of the Council of 25 November 2015 on novel foods, amending Regulation (EU) No 1169/2011 of the European Parliament and of the Council and repealing Regulation (EC) No 258/97 of the European Parliament and of the Council and Commission Regulation (EC) No 1852/2001. Off. J. Eur. Union 2015, 327, 1-22. 